\title{
AN ASSESSMENT ROLE OF AMISOM IN THE PEACEBUILDING PROCESS IN SOMALIA: A STUDY
}

Abdullahi Ahmed Ali ${ }^{*}$, Neelam Pandey ${ }^{2}$

\author{
1*PhD Research Scholar, Department of Political science \& Public Administration, Annamalai University, Tamil Nadu, \\ India; ${ }^{2}$ Associate Professor, Department of Political Science \& Public Administration, Annamalai University, Tamil \\ Nadu, India. \\ Email: ${ }^{*}$ abdulahiahmed2015@gmail.com, ${ }^{2}$ neelam.pandey.66@gmail.com
} Article History: Received on $10^{\text {th }}$ April 2020, Revised on $26^{\text {th }}$ May 2020, Published on $20^{\text {th }}$ June 2020

\begin{abstract}
Purpose of the study: The aim of this study is to examine the role of AMISOM in Somalia's peacebuilding process in terms of disarmament, demobilization, and reintegration (DDR) and reconciliation among Somali clans.
\end{abstract}

Methodology: This study uses a descriptive design with document analysis to attain the research objectives. Secondary data is used. The data are collected from books, articles, journals, and literature on peacebuilding.

Main findings: The results show that AMISOM has no significant role in disarming, demobilizing, and reintegrating clan militias into communities. The AMISOM reconciliation process has not succeeded to bring Somalis together to determine how key issues are negotiated.

Application of this study: This research is useful for peacebuilding practitioners and government/policymakers in identifying the drivers, causes of armed conflicts in Somalia.

Novelty and originality: While other studies focused on the impact of power-sharing in rebuilding the Somalia government, the present study examines the impact of DDR, tailored with reconciliation in clan co-existence and silencing clan conflicts.

Keywords: Peacebuilding, Reconciliation, Disarmament, AMISOM, Armed Conflict, Civil War.

\section{INTRODUCTION}

The Somalia military government collapsed in 1991 following the emergence of clan-based militant factions. These groups were led by clan opposition Politicians seeking to overthrow the Somali military government engaged in fighting. These groups were organized as clan militants, and jointly they ousted Said Bare military government. This has trapped Somalia into protracted civil war and consequent of humanitarian grief (Waldman,2018). The civil war and tensions trace to the dictatorial regime, Mohamed Said Barre. Subsequently, the collapse of the military system, Somalis fought along clans lines. After a short while, the large clans fought among themselves to control the primary resources income in the country (Mushtaq, 2017). Thus, Somalia has been characterized by disagreements over governance structure, a lack of shared common vision of national reconciliation, and shared common future amongst Somalis. In response to the escalating tensions of the country, the United Nations initiated Peacekeeping Operations for Somalia to restore peace and order. The UN deployed first peacekeeping operations to Somalia; UNSOSOM 1 (1992-93) and UNSOSOM II (1993-95) (Thakur, 2008).

Nevertheless, the situation of Somalia continued to deteriorate, and the UN had not received any cooperation from clanbased militants, and these circumstances and critical conditions posed by warring factions compelled United Nations peacekeeping operations to withdraw from Somalia without any achievements. However, on 19 January 2007, following a UN failure, the African Union Peace and Security Council created the African Union Mission in Somalia (AMISOM) as a peacekeeping force in Somalia with a mandate from the UN Security Council. The Mission has five sectors which consist of 22,126 troops from Uganda, Ethiopia, Kenya, and Burundi (Williams, 2019). The primary objectives of the Missions are to help the federal government expand its rule over the country, I to support the security environment in promoting the political process at all levels, and the national reconciliation and peacebuilding efforts in Somalia; (ii) to create a conducive atmosphere for the disarmament, demobilization, and reintegration of ex-combatants (III) to support the gradual transition of security responsibilities from AMISOM to the contingent Somali national forces. However, most empirical studies in Somalia evaluate AMISOM effectiveness only in terms of conflict prevention. This leaves a large gap that AMISOM peacebuilding is elusive. However, this study aims to examine the role of AMISOM in Somalia's peacebuilding process in terms of disarmament, demobilization, and reintegration (DDR) and the study seeks to determine reconciliation among Somali clans.

\section{LITERATURE REVIEW}

The term 'Peacebuilding' firstly emerged in the field of conflict and peace by Johan Galtung in mid -1970s (Mason, 2006). Peacebuilding involves effort attempt to create a peaceful alternative to the civil war that underlies conflict (Jeong, 2011). Peacebuilding promotes in reducing conflict by addressing cultural and structural causes of the violence and has three main features; it is a process that designs to address the root cause as well as a source or symptoms of conflict and its well-suited mechanism to the countries with internal conflicts. Peacebuilding can take place at multiple 
stages of the society, from the community level to the national level. It is a long-term process without a bright start or endpoint. Peacebuilding can be signed before, during, and after conflict. (Murithi, 2009). Boutros-Ghali describes "peacebuilding" as an effort to recognize and maintain mechanisms that aim to reinforce and solidify peace to avoid a recurrence of conflict. The definition implies a fairly institutional view of peacebuilding, including activities such as reconciliation, rebuilding security institutions, and disarmament, demobilization, and reintegration re-establishing core functions of government, and supporting economic recovery.

Disarmament, Demobilization, and Re-integration (DDR) as a process that creates greater stability and reduces security threats (Knight, 2008). The DDR aims to disassemble conflicting groups' weapons, armies, and camps that make societies resilient for preventing violence (Knight, 2008). The DDR process consists of three stages. The first two phases are designs to deal with hard threats to security while the third step by peacebuilding and tries to end militants' incentives for fighting. The first phase, disarmament, consists of removing guns and weapons from former rivalry groups, storing weapons safe places, and eventually destroying them. Demobilization is another process that is dismantling various armed groups, shutting down militant camps, and separating former combatants from militant groups. The final step is reintegration combatants endeavor to return to their former homes or new locations. This phase the combatants receive jobs, trauma healing, psychological counselling, and education to return to their previous lives and reintegrate into the community (Joshi, 2017). Reconciliation plays a critical role in the reintegration of victims and perpetrators, foster apologies and forgiveness, promote and reconstruction relations between societies (Zambakari, 2018). Reconciliation is closely linked to restorative justice. Reconciliation may include restoring broken relationships between racial, tribes, religious, regional, or political groups, between neighbours, and between political parties, reconciling with their past, and groups combining (Jack, 2018). Kriesberg (2007) defines "reconciliation" as a process of reconciliation between previously antagonistic enemies or groups. Bar-Tal and Bennink (2004) Describes the "Process of reconciliation as 'the restoration of damaged relations of the societies.

Promoting reconciliation as the only way forward and necessary for future peace and development. According to Montville, true reconciliation involves sequencing of three steps: 1) Acknowledgment when oppressors genuinely acknowledge to public or victims the acts which they have committed, that acknowledgment should be a real and victims are at least guaranteed that the past does not repeat. 2) Apology/remorse, the next important step is to take the responsibility of past actions, oppressors to express their regret, sorrow, and directly request forgiveness from victims. 3) Forgiveness/ aggressors' first two measures allow the actual end acceptance, which is the victim's voluntary acceptance of previous injuries by the oppressors. In Somalian, the process of reconciliation is conceived as a form of restoration of justice that would bring together the perpetrators and victims with the goal of correcting past, restoring destroyed relationships, healing with harmony, and unite.

\section{Theoretical framework}

This study aims to deal with two research variables. This study will examine the importance of Disarmament, Demobilization, and Reintegration (DDR) and reconciliation in the peacebuilding process.

The diagram below is showing the theoretical framework of the study:

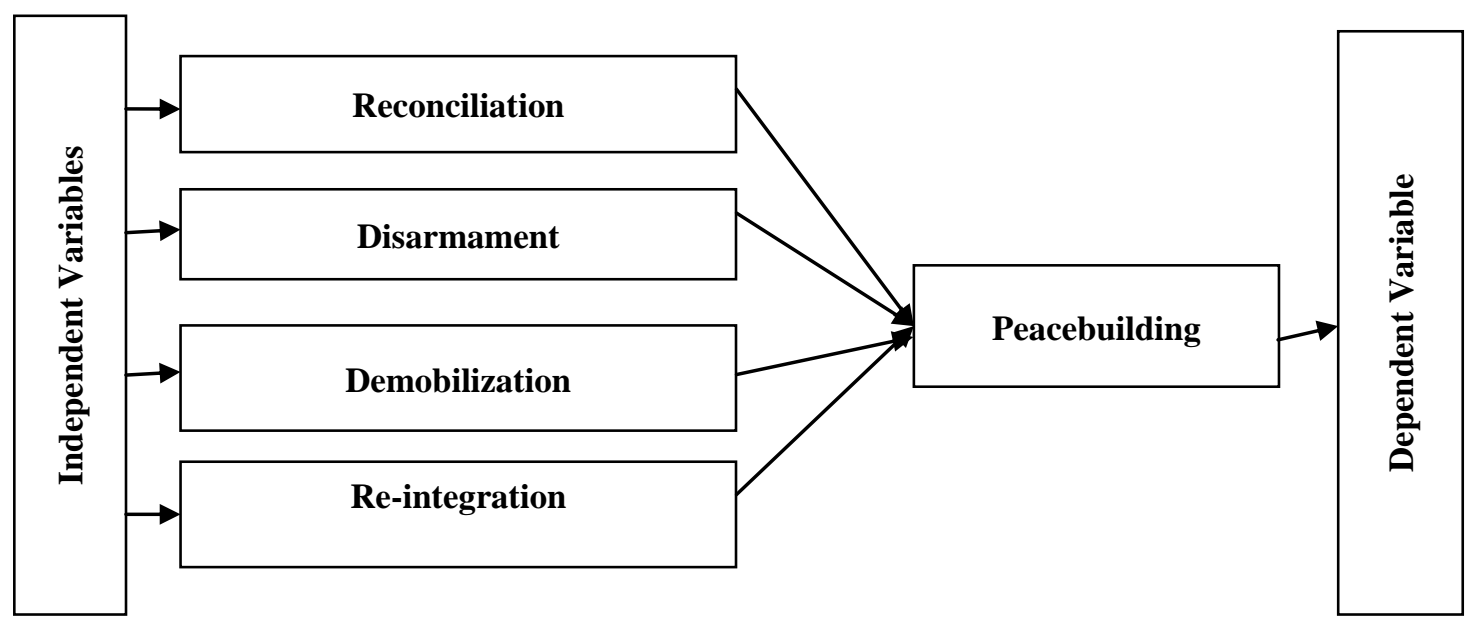

Figure 1: Research Variables

\section{METHODOLOGY}

The study will adopt a descriptive research design to achieve the objectives of the study. In this study, the descriptive design will be employed to present-oriented methodology and to investigate secondary data (Tayie, 2005). This study used secondary data which is useful to the Peacebuilding. The secondary data is obtained from books, Articles, Journals, 
and peacebuilding literature. The variables of this study are Reconciliation, Disarmament, Demobilization, and reintegration (DDR).

\section{Reconciliation}

For more than thirty years, Somalia has been still on the way of reconciliation process after many decades of divisionism between Somali clans which culminated in the fall of the military government 1991. Somalia now is healing past wounds. Somalia National reconciliation, which is crucial for the restoration of national unity and political stability, is on the way (Ken mmenkhaus, 2018). To understand the causes and consequences of Somalia conflict this is the center for the productive and successful reconciliation process. The study is identifying two sources of clan conflicts: (I) Rural, (II), and Urban settings. The causes of these conflicts and scale are differing. Still, most of it often starts a dispute over resources between small numbers of groups which ultimately transforms into direct clashes among clans. In rural conflict settings, two core sources have been identified: among nomads, access to resources (water and pasture) often used for grazing livestock in Somalia. In Urban areas, in respect of urban settings, there are two main conflicts: land grasp and politically motivated conflicts. This situation has contributed to three main factors: lack of effective central government; proliferation in civilian hands of weapons, and the weakness of the law enforcement specifically, police and the courts, in town as much as rural settings (Omer and Hersi, 2018).

\section{Revenge killings}

In addition to the two primary sources of conflicts mentioned above, revenge killings, in the context of Somalia is the main source of clan-based conflict since the collapse of the central government 1991 (Elmi, 2006). These revenge killings it usually starts as a minor episode between two individual level or two groups, but instantly escalates the devastating conflict between two clan lines. The majority of revenge killings are a drag on, sometimes for a generation. For example, there are two current cases of revenge killings between clans in Kismayo, Walwyn, and Dinsor in Somalia. In the absence of the strong functioning government role to contain, control, deter and solve conflicts, Somali clan delegated elders have come to play a vital role in resolving clan conflicts through customary and sharia law(Mohamed Haji, 2016). Customary and sharia law is one of Somali's tools for conflict resolutions between or among clans in Somalia.

This figure shows that how traditionally Somalia solve clan disputes through customary law (Xeer):

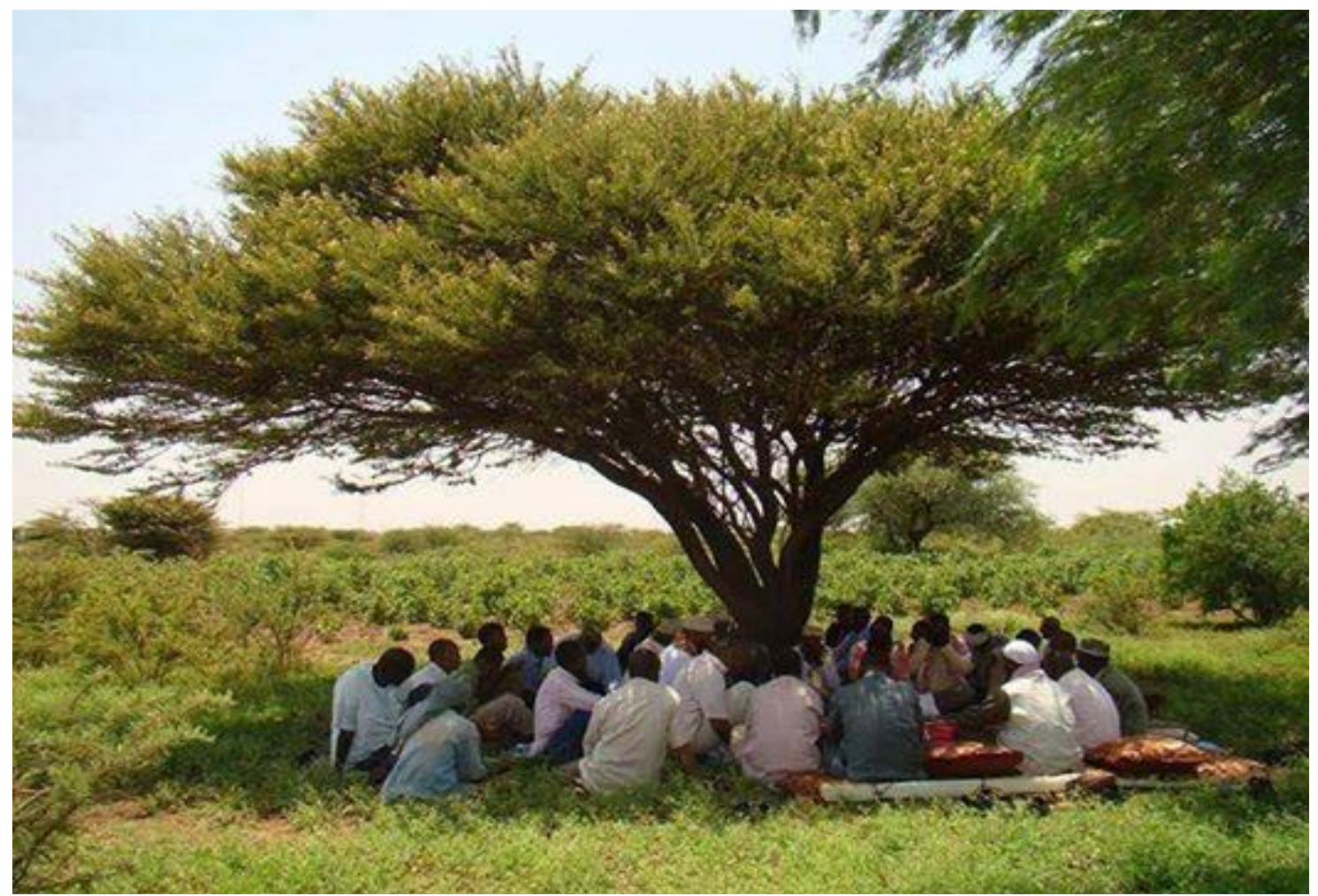

Figure 2: The Somalia different clan Elders Council meet under trees to discuss conflict management and reconciliation among clans

Source: BBC Somali News

This below figure shows that traditionally Somali women play a major role in conflict resolution in society. 


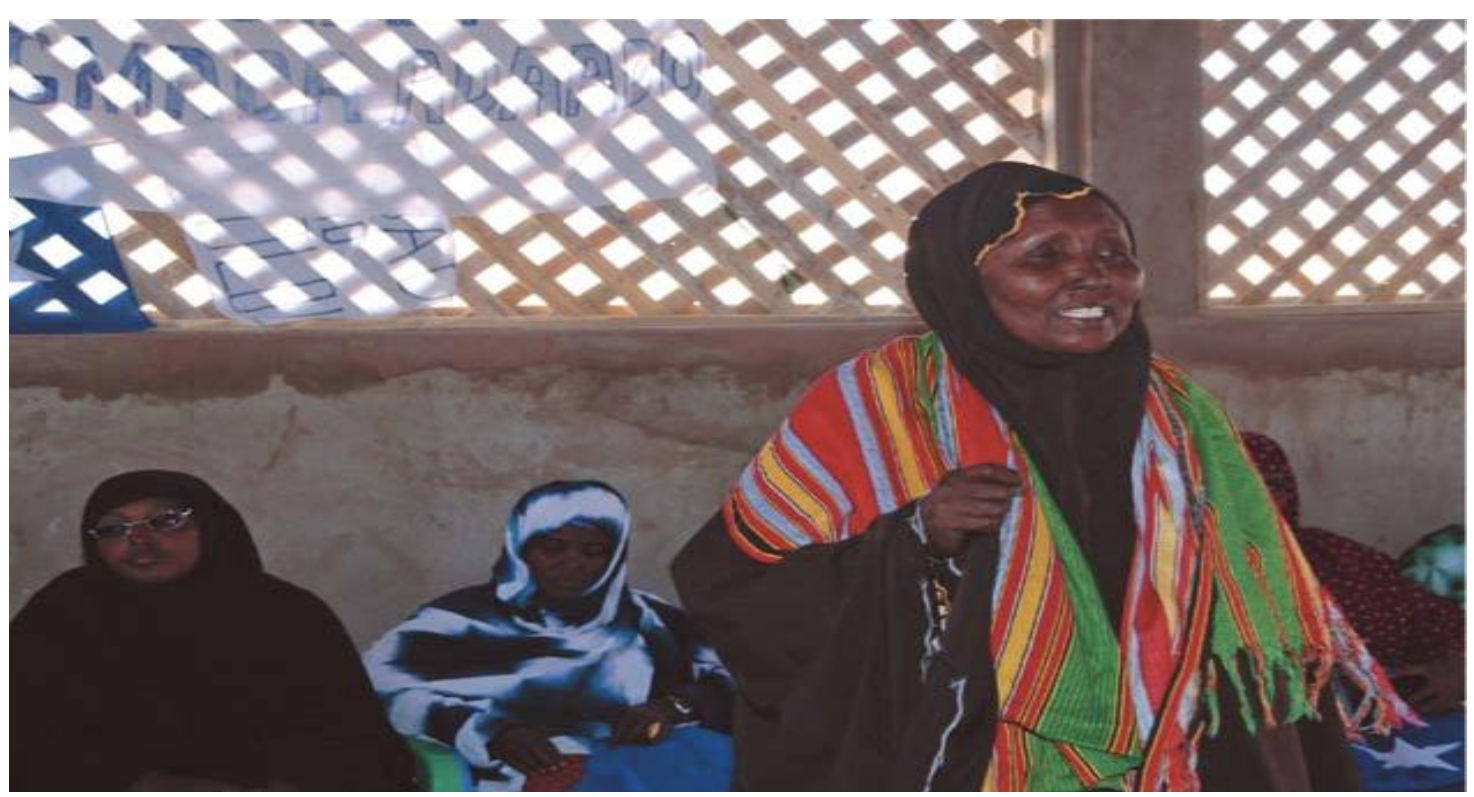

Figure 3: A woman from the women's pressure group encourages the elders to drop the past grievance and focus on the future at the Adado meeting, 16 February 2007.

Source: BBC Somali News.

However, the conflict dynamics created influential clan-based faction leaders who undermined the authority of traditional leaders and the effectiveness of traditional conflict resolution mechanisms.

\section{History of Somalia National Reconciliation Process}

In 1991, the first attempt at reconciliation was the first effort to reconcile the various parties following the fall of the central government in Somalia. In the June 1991 conference which was held in Djibouti, to restore the Somali government. Six of the various warring groups participated in the meeting, supporting Ali Mahad as Somalia's president. But among both, General Farah aidid rejected and civil war broke out in Mogadishu1993 conference on national reconciliation.

\section{Somali National Reconciliation 1993}

Somali's fifteen divided civil war engagement in March 1993, concluded two national peace and disarmament agreements to resolve the bloody civil wars. But wars persisted, and agreement felt apart.

\section{7 national salvation council}

The international community organized a National Conference on Reconciliation in Sodere, Ethiopia, in January 1997. The conference established a National Salvation Council (NSC) of 41 members responsible for coordinating a transitional government. Nevertheless, General Hussein Farah opposed it.

\section{Somalia National peace conference}

Contrary to previous reconciliation meetings, the majority of Somalis attended the conference in Arta, Djibouti, civil society, academicians, clan and religious figures, and the business sector. The meeting, a transitional national government (TNG), formed Somalia's first government since 1991. And Somalia secures international legitimacy, enable Somalia to re-occupy its UN and regional seats. Furthermore, the Somalia Council for Reconciliation and Restoration Council (SRRC), which were a tribal warlord from various parts of Somalia, resisted the government.

\section{National reconciliation conference}

Eldoret Kenya in October 2002, In an attempt by the Intergovernmental Development Authority (IGAD) to reconcile the transitional national government (TNG) with the opposition group Somalia Council for Reconciliation and Restoration Council(SRRC), before the end of the National Government's mandate. Ultimately, this conference brought a cease-fire compact reached by 24 separate clan delegates requesting that a federal system be created, reconfiguring the unitary government set up in Arta.

\section{National reconciliation conference}

In September 2003, the Somalia National Reconciliation Conference was held in Nairobi Kenya by the Intergovernmental Authority on Development (IGAD), the African Union and the UN. The conference was reconciled 
with the transitional government and Somalia Reconciliation Restoration Council (SRRC). Participants unanimously decided to adopt a structured federal transitional charter.

\section{The Nairobi Conference}

A meeting was held in Nairobi Kenya in January 2004, whereas major factions signed a declaration on harmonizing the various aspects proposed by delegates to the meeting. This conference set up a transitional federal government parliament in August 2004, the presidential election, and finally, the parliament gave confidence vote to a prime minister. It formed Somalia's first national government since the fall of the unitary government in 1991

The cornerstone of the national reconciliation process in Somalia is a 2008 Djibouti-based peace agreement between the Transitional Federal Government (TFG) and the Somalia Liberation Alliance (ARS), which is intended to pave the way to end all violent conflicts across the region. This resulted in the widening of the Parliament from 275 to 550 members, taking in parliamentarians from ARS and also an enlarged cabinet that is the latest step a broader national reconciliation process which ended the Transitional Federal Government in 2012. It was the first time elected Parliament and President in Somalia August in 2012 (Barawani, 2017). The 2017 national reconciliation conference held in Somalia capital Mogadishu was the first attempt to address national-level clan reconciliation. As so far Somalia Government institutions have been gradually restored, several national reconciliations held in Mogadishu, although the Federal Government is weak to reconcile various clans and exercises its control over the country. What does it mean reconciliation in the Somalia context, reconciliation is the consensus of Somali citizens who share the same culture, who have common nationality, Somalis characterized by tolerance, trust, mutual respect, equality, truth and healing of one another's wounds caused by civil war to lay the foundation of sustainable development (Abdurahman, 2019). Attaining of unity and reconciliation between Somalis clans requires profound transformation and willingness of Somali society into a reconciled and united state in which all Somali citizens have equal freedom and a country that has a common vision for a better future.

The reconciliation process is unquestionably crucial for the stability of the Somali state. The political framework, peacebuilding, and constitutional arrangement will all be focused on the results of the negotiation process. Ideally, the process of reconciliation should be established and directed by an autonomous committee in Somalia which is not set up by any government. Due to negative experience with the past reconciliation process for the reason that past governments and the current reconciliation process in Somalia tended to involved small groups of the elite with no interest in reconciliation (Abdullahi, 2015). Interestingly, the reconciliation process in Somalia, effected by subjective factors as mistrust, misperceptions, fear, hostility, suspicion among Somali clans because they fought to each other for two decades. In a circumstance, where clans yet suspicious of each other, the Process, therefore, should bring changes of clan perceptions and bring towards behavioral changes. According to Montville, true reconciliation involves sequencing of three steps: (1) Acknowledgment when oppressors truly accept what they have done to the public or victims, the recognition becomes a reality, and victims are at least assured that the past does not repeat. (2) Apology/remorse, the next significant step is to accept responsibility for past acts, showing guilt, sorrow and specifically asking the victims to forgive (3) Forgiveness, the oppressors' first two measures allow true final forgiveness, which is the victim's voluntary forgiveness of past injuries by oppressors. Consequently, all these three essential elements are missing last fourteen Somali reconciliation process which was held in Kenya, Djibouti, Ethiopia, Egypt, Yemen and Sudan, all who involved the Process were representatives of different Somali clans and, they were not prepared to appeal forgiveness, apology, and acknowledgment among them and their victims (Debora, 2019). Although the current federal government is the outcome of those processes, still the government is struggling to acquire the legitimacy from Somalis which will enable to facilitate nationwide reconciliation and conduct universal suffrage, one man, one vote.

The important step for Somali clans is accepting and supporting the idea of a reconciliation process and determining how to resolve clan disputes and grievances which could involve forgiveness among clans. To do so, Somalia needs bottomup true reconciliation process, and this is where AMISOM Mission reconciliation process is intended to address and reinforce reconciliation and provide essential support to Somali federal government but the AMISOM Mission has overlooked bringing Somalis together to decide how key problems that are likely to require reconciliation, and justice are addressed. Considering that, the AMISOM Mission has to make sure that process of reconciliation can be derived from bottom-up, inclusive for all clan factions in Somalia. Reconciliation is a process that transforms the nature of the relationship between victims and perpetrators aiming to create a new relationship for a peaceful common future carried out by a third party (Bennink, 2004). In the context of Somalia, AMIOSM Mission did not transform the relationship between victims and their perpetrators, trauma healing, and confidence-building between various clans which would have a crucial role in the peacebuilding process in Somalia. The reconciliation process is the most effective way to achieve unity and social cohesion in Somalia. The reconciliation is the only approach that addresses the key issues include security, constitution, federalization, division of the political crisis, and the process of disarmament, demobilization and reintegration (DDR) In a situation such as Somalia, where violence still prevails, the clan war is that reconciliation is not sufficient on its own; other components of peacebuilding, such as economic reconstruction, social welfare, are essential to the careful stabilization of the country. (Paul Quigley, 2018). 
Compared to other similar peacekeeping missions involving the reconciliation process, such as the United Nations Mission in Liberia 2003 and the United Nations Mission in Sierra Leone 2005. The UN established a Truth Reconciliation Commission in Sierra Leone and Liberia which is not set up in Somalia. The United Nations achieved remarkable success in Sierra Leone and Liberia by addressing the structural causes of conflicts and adopting comprehensive reconciliation between various groups (Shaw, 2007). The AMISOM Mission has failed to establish truth and reconciliation commission in Somalia and facilitated bottom-up reconciliation, driven and led by Somalis, AMISOM'S primary purpose is to secure the space in which the various elements of clan conflict can be resolved through dialogue, reconciliation, and negotiation. AMISOM has not achieved this objective yet by created conditions conducive for agreed national settlement which is inclusive, comprehensive, and holistic approaches to solve clan conflicts. Since the collapse of the central government, there has no genuine national reconciliation in Somalia. The Clans are deeply divided for past cruelty among them, and each clan has fought to others to control resources. In this regard, AMISOM, therefore, has attempted to solve these critical issues nevertheless, AMISOM has not made a significant contribution to stabilizing Somali, primarily, in the settlements of clan conflicts, empowering traditional reconciliation mechanisms and bring consensus among them. For example, AMISOM has not established clan level reconciliation committee, include eminent elders, clan leaders, religious leaders and other individuals who highly respected by Somalis who could be trusted to proceed reconciliation among Somali clans, not to have vested interests in politics, and who have necessary skills to connect various clans in the society. Most Importantly, AMISOM has lacked an effective and legitimate set of Somali families to manage a successful reconciliation among groups, and this is a fundamental problem that AMISOM is facing in the reconciliation process.

\section{Disarmament, Demobilization, and Re-integration}

After Somalia's central government collapsed in 1991, Somalia has been characterized by armed conflict and subsequent lack of consensus about what political and economic structure and form of government to develop. $\mathrm{n}$ the apparent lack of functioning centralized security oversight, clans, and local armed groups have proliferated widely to provide security to their clans and sub-clans. When militias grew from sporadic to permanent security providers, they often became selffinancing, the main revenue instruments, e.g., maintaining illegal infrastructure points. The Somali national army forces in the current state cannot adequately exercise authority on the areas operated by various clan militants. Therefore, one of the objectives/mandates of AMISOM is to have adopted an effective Disarmament, Demobilization, and reintegration (DDR) by disarming, demobilizing, and reintegrating the clan militias into communities. Since Disarmament, Demobilization, and Re-integration is seen as a central place in the peacebuilding, Social cohesion, peace, security, and development in Somalia and also a key pillar for stabilization and reconstruction Robin (1993).

\section{Sources of armed conflict in Somalia}

In Somalia, numerous factors lead to armed conflict, These factors include (i)terrorism, (ii) clan-motivated inter-clan violence (Tribe) resource control force, (iii) group conflicts, and (ii) individual crime. The above categories are not necessarily exclusive, as conflicts overlap, overlap, and sometimes change to one type. Sixteen separate militant groups exist in 2016, according to the Armed Conflict Location \& Event Data Project (ACLED).

The graph below shows that conflict incident by major conflict party from January 2011 to November 2016:

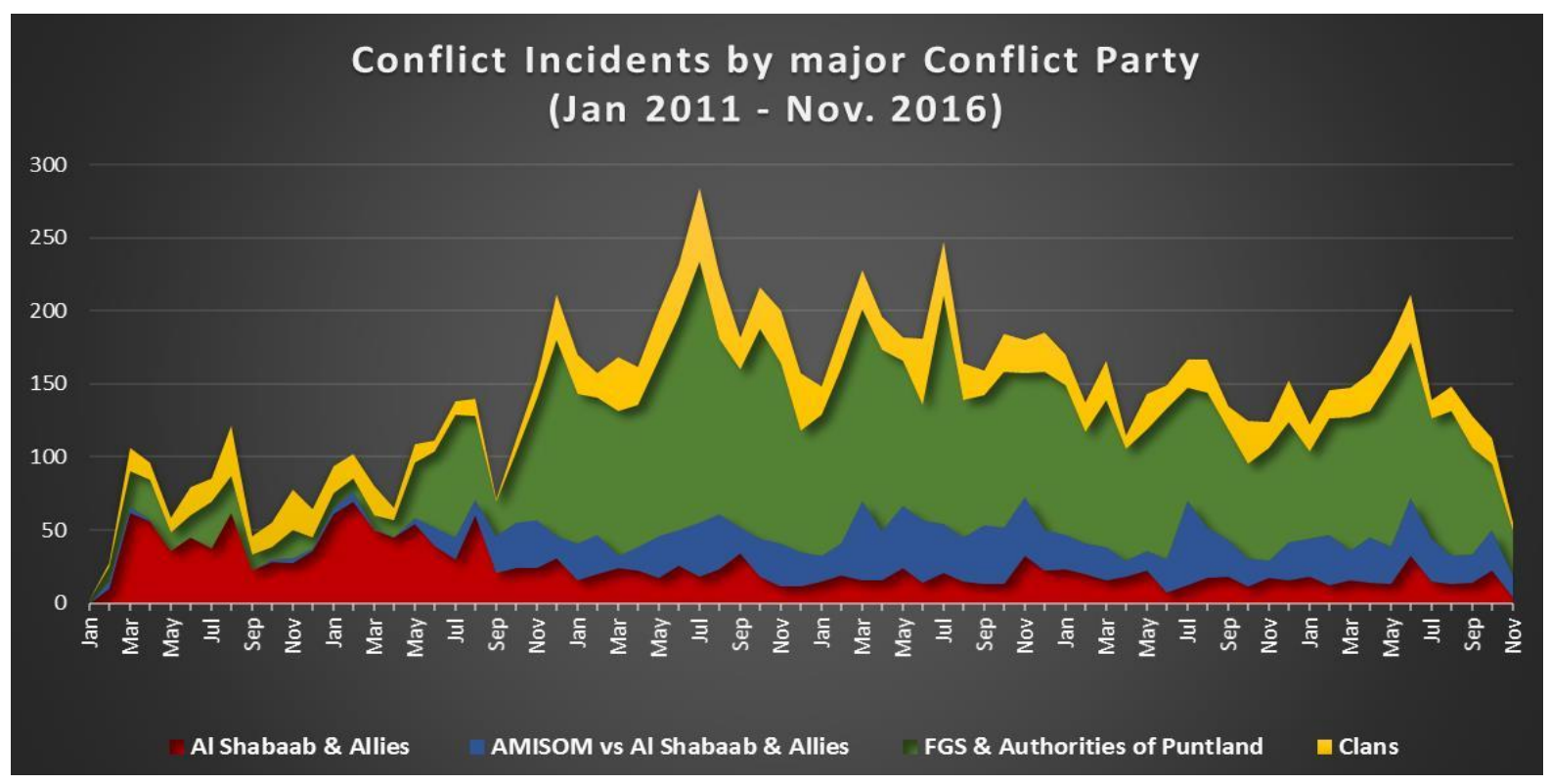

Figure 4: Conflict Incidents by major conflict part (Jan. 2011-Nov. 2016)

Source: The Armed Conflict Location \& Event Data Project (ACLED), (as of November 2016) 
The table below displays the number of reported attacks by involved party groups:

Table 1: Violent Conflict and Conflict Fatalities

\begin{tabular}{llllll}
\hline & Violent conflict & \multicolumn{3}{l}{ Conflict Fatalities } \\
Year & AL-Shabab \& Alias & AMISOM VS Al-Shabab & $\begin{array}{l}\text { FGS\& Authority of } \\
\text { Puntland }\end{array}$ & Clans & Sum \\
\hline 2011 & 421 & 17 & 193 & 186 & 817 \\
\hline 2012 & 508 & 159 & 559 & 159 & 1,385 \\
\hline 2013 & 240 & 302 & 1,417 & 392 & 2,351 \\
\hline 2014 & 220 & 423 & 1,287 & 311 & 2,241 \\
\hline 2015 & 197 & 291 & 1,009 & 253 & 1,750 \\
\hline 2016 & 173 & 287 & 867 & 220 & 1,547 \\
\hline Sum & 1,759 & 1,479 & 5,332 & 1,521 & 10,091 \\
\hline
\end{tabular}

These armed groups continue to exist alongside the Somalia national army, and in even some instances are better equipped and more effective than the Somali national army. They are operating out of government control, and they are still in possession of heavy weapons and small arms. They can pose a menace to the security of Somalia and its Peacebuilding process. The integration of these various clan militants and other regional forces into Somalia's national army continues to be the primary goal of the Somali federal government. However, there have been practically no integrated national plans developed for DDR to back clan militias into a productive life and generally contributed to the failure of AMISOM to manage armed conflict because of the lack of political agreement on DDR in Somalia, that have been complicated AMISOM Mission to achieve its core mandate. At the same time, the Somali federal government (FGS) has also failed rigorously to contain clashes often due to the conflict generating by various groups, including the clan militias and Al-Shabaab.

Generally, The DDR phase includes three main components: the surrender of arms, the successful discharge of fighters, and the reintegration of ex-militias into their society. The AMISOM's primary mandate was to discharge the active clan militias, surrender their weapons, and re-integration into the community, provide essential training for the Somali army, police force, enabling Somali national security forces to take security responsibilities of their own country. But the primary objectives that AMISOM Mission has been established in Somalia have not been achieved yet. The AMISOM DDR program failed to collect the sizeable number of weapons, dismantled various clan militias and their military organizations, and shifting from militant to civilian status. Although AMISOM launched a national program for clan militias and other armed groups, with the cooperation of the UN Assistance Mission in Somalia (UNSOM), amid public criticism from Somalis, Mogadishu, Kismayo, Baidoa, and Beletwyane have formed at least four transition centres. These centres set up to deal with armed disengagement groups. AMISOM and the federal government expected to facilitate the return of militias back into communities under the protection of these centres. Still, these centres are not merely a convenient way to deliver assistance, training, and education. For example, the centres lack the planning of registration and processing permanent cantonment sits, exchanging of weapons for money, the provision of training, and employment to the militias.

Disarmament includes the capture, identification, monitoring and disposal, ammunition, explosives, and heavy weapons in conflict zones (Andy, 2008). Initiated arms control programs such as safe storage and destruction of Clan militia weapons in different parts of the country. While AMISOM assisted the federal government in developing a national strategy to treat and handle fighters to reintegrate into their society. in spite that Disarmament, Demobilization, and reintegration of armed groups are still posing a considerable challenge to the Peacebuilding and stability of Somalia. Disarmament of clan militias, though, requires comprehensive negotiated agreement between Clans, has never been achieved. In May 2017, the political settlement around the national security architecture agreed but remained doubtful because every clan sees their weapons as necessary for self-protection. And the groups perceive that their weapons will guarantee security and political participation or on the other way, clans feel threatened if would seize their weapons by AMISOM. Successful Disarmament needs the length of greater inclusivity by balancing the power of the clans, and also strengthening the security institutions and developing inclusive national security architecture. This approach will lead to greater sustainable peace in Somalia.

The DDR process that is shared, trusted, inclusive is crucial to peacebuilding whether clan and national level. This process needs to gain trust confidence of the groups often, increasing through establishing local governance arrangements, strengthening justice, and delivering essential services. There are, however, some crucial elements which should incorporate DDR process in Somalia, particularly, establishing the National Commission for DDR would facilitate the planning of the program and oversight the operations at the national-level disarmament, demobilization, and reintegration, which would promote comprehensive agreements between clans, AMISOM, and the Federal Government. However, AMISOM has not success creating a national commission for Disarmament, Demobilization, and reintegration in Somalia, which would be essential to peacebuilding and disarming various armed groups. AMOSM has created the space for peacebuilding and reconciliation in the country. It should support all major clans and sub-clans to involve the DDR process and make progress in a DDR that will be the best approach for the possibility of successful 
peacebuilding in Somalia. The DDR process of AMISOM is expected to foster peace agreements between clan militias, rebuild and restore clan relations, and promote economic opportunities for clan militias. But the result of AMISOM of these DDR process is far from even in the ground reality of Somalia. In a comparison of some other similar peace Missions, the United Nations Mission in Liberia's DDR program 101,495 ex-combatants were disarmed, demobilized and reintegrated back into the community. In Sierra Leone 2005 DDR program 75,000 ex-combatants were disabled by the UNOSMIL, 69,000 combatants went through the demobilization process; under the reintegration process; Through the military integration program, 2,600 combatants have integrated Sierra Leone national army. Meanwhile, AMISOM Mission DDR in Somalia is an extremely challenging exercise. And AMISOM Mission was unable to deliver on its mandate to disarm, demobilize and reintegrate various armed groups in Somalia.

\section{CONCLUSION}

Combined with reconciliation, disarmament, demobilization, and reintegration continue to play a key role in the peacebuilding process as it leads to a stable atmosphere for permanent peace. It should also bear in mind that directly linked to opportunities to transform the overall security sector after post-conflict situations end. At the same time, Somalis-driven bottom-up reconciliation process has a possibility of increasing trust between clans and provides a common basis for building a new, secure Somali state. The study recommends that AMISOM improve the areas it failed to create such as the National Reconciliation Commission and the National Disarmament, Demobilization, and Reintegration Commission.

\section{LIMITATION AND STUDY FORWARD}

Despite the attempt to make some contributions, this study is, therefore, restricted the role of AMISOM in the Peacebuilding Process in Somalia, in considering factors that play a key role in peacebuilding. Future studies could expand the rule of law, economic recovery, and in fact that these variables play an essential role in peacebuilding.

\section{CONFLICT OF INTERESTS}

The Authors of this study confirm that they have no conflict interests.

\section{ACKNOWLEDGMENT}

The authors of the study are sincerely grateful to the Department of Political Science \& Public Administration Annamalai University for providing the necessary support during the research process.

\section{AUTHORS' CONTRIBUTION}

The First Author Contribution was involved in drawing up the paper collecting the data, and interpreting the results. The second author was involved in planning and supervising the research, helping in drafting the manuscript, correcting and revising the paper to improve manuscript quality.

\section{REFERENCES}

1. Abdulahi, A. O. (2015). The End of Transition in Somalia and the Role of the Technical Selection Experience. JOURNAL OF SOMALI STUDIES, Volume 2, Numbers 1 \& 2, (1 \& 2,), PP-25-36.

2. Abdurahman, B. (2019). Somali National Reconciliation: Exploring a Comprehensive ApproachExploring a Comprehensive Approach. Journal African Security Review .

3. Aden, A. (2019). PROMOTING NATIONAL PEACE AND RECONCILIATION Reconciliation in Somalia: Reform, Representation and Responsibility. Mogadishu: World Bank Publications.

4. Barawani, M. A. (2017). SOMALILAND AND SOMALIA PEACE- BUILDING PROCESS: ACTORS, INTERVENTIONS, AND EXPERIENCES. (pp-17-26, Ed.) International Journal of Development Research, Vol. 07, I (Issue, 08).

5. Debora, M. (2019). Destabilising Interventions in Somalia Sovereignty Transformations and Subversions (Vol. 1st Edition). London: Rountledge.

6. Elmi, A. A. (2006). The Somali Conflict: Root causes, obstacles, and peace-building strategies. Journal African Security Review , PP-16-22. https://doi.org/10.1080/10246029.2006.9627386

7. Ho-WonJeong. (2011). Approaches to Peacebuilding (Vols. vol. 5, no. 1). New York,: Springer.

8. Jack, A. E. (2018). Wars and Conflicts in Sub-Saharan Africa/The Middle East and North Africa. Journal of Global Peace and Conflict, Vol. 6, (No. 2,), PP-9-14. https://doi.org/10.15640/jgpc.v6n2a3

9. Joshi, M. ( 2017 ). Explaining demobilization in the wake of civil conflict. Journal Peacebuilding, Volume 5, (ssue 3), PP-24-28. https://doi.org/10.1080/21647259.2016.1268345

10. Ken mmenkhaus, I. A. (2018). War and Peace in Somalia National Grievances, Local Conflict and AlShabaab. (M. K. WALDMAN, Ed.) London: Oxford University Press.

11. Knight, W. A. (Aug 2008, Aug ). Disarmament, Demobilization, and Reintegration and Post-Conflict Peacebuilding in Africa: An Overview. Journal African Security, PP-19-28. 
12. Knight, W. A. (Volume 1, 2008). Disarmament, Demobilization, and Reintegration and Post-Conflict Peacebuilding in Africa: An Overview. Journal African Security , Volume 1, (Issue 1,), PP-9-16. https://doi.org/10.1080/19362200802285757

13. Mason, T. D. (2006). Conflict Prevention and Peacebuilding in Post-War Societies. London: Rountledge. https://doi.org/10.4324/9780203087367

14. Mohamed Abdi Omer and Mohamed Farah Hersi. (2018). Exploitation of Natural Resources as a Driver of Conflict: Case Study on Mining in Baki District, Somaliland. London: Oxford Unversity Press.

15. Mohamed Haji, E. (2016). The Suicidal State in Somalia The Rise and Fall of the Siad Barre Regime, 19691991. Lanham: University Press of America.

16. Murithi, T. (2009). THE ETHICS OF PEACEBUILDING. Edinburgh: Oxford University Press.

17. Mushtaq, N. (2017). State-building Amidst Conflict: The Urgency of Local Reconciliation. New York: Oxford University Press.

18. Paul D. Williams. (2019). ssessing the Effectiveness of the African Union Mission in Somalia (AMISOM). Cairo: Cairo Centre for Conflict Resolution, Peacekeeping and Peacebuilding (CCCPA).

19. Paul Quigley, J. H. (2018). Reconciliation after Civil Wars Global Perspectives (Vol. 1st Edition). London: Sage. https://doi.org/10.4324/9781351141802

20. Shaw, R. (2007). Memory Frictions: Localizing the Truth and Reconciliation Commission in Sierra Leone. International Journal of Transitional Justice , Volume 1, (Issue 2, ), PP.17-27. https://doi.org/10.1093/ijtj/ijm008

21. Tayie, S. (2005). Research Methods and Writing Research Proposals. Cairo: Centre for Sdvsncement of Post Graduate Studies and Research in Engineering Sciences, Faculty of Engineering-Cairo University (CAPSCU).

22. Thakur, R. (2008). From Peacekeeping to Peace Enforcement: The UN Operation in Somalia. The Journal of Modern African Studies, Volume 32 ( 03), PP-10.21.

23. WALDMAN, M. K. (2018). War and Peace in Somalia National Grievances, Local Conflict and Al-Shabaab. New York: Oxford University Press.

24. Zambakari, C. D. (2018). Conceptualizing Reconciliation in Transitional Processes. A Journal of Social Justice , Volume 30, (Issue 3.), PP-12-21. https://doi.org/10.1080/10402659.2018.1496996 